\title{
The Analysis on Income of Beef Cattle Breeders in Various Crop Patterns in Umbulsari District, Jember Regency
}

\author{
Noer Soetjipto $^{(1)}$, Zaenal Fanani ${ }^{(2)}$, \& Nanang Dwi Wahyono ${ }^{(3)}$ \\ ${ }^{1}$ Universitas Muhamadiyah Malang, ${ }^{2,}$ Universitas Brawijaya, ${ }^{3}$ Politeknik Negeri Jember \\ E-mail:2prof_zaenalfanani@yahoo.co.id,
}

Received: 18 January 2018; Revised: 12 March 2018; Accepted: 10 May 2018

\begin{abstract}
Abstrack
The objective of research is: (1) to analyze the cost incurred at integrated farming involving beef cattle breeding and various crop patterns; (2) to estimate the revenue received from the integrated farming involving beef cattle breeding and various crop patterns; (3) to find out the income obtained from the integrated farming involving beef cattle breeding and various crop patterns; and (4) to acknowledge the balance of revenue and cost of the integrated farming involving beef cattle breeding and various crop patterns. Research was located in Umbulsari District, Jember Regency, starting from 16 June 2016 to 28 September 2016. Sampling frame technique used in this research is Two-Stage Cluster Sampling. Both sampel and location of research are determined with purposive sampling. The analytical model of research is the analysis on cost and revenue of livestock-crop farming. Research indicates some results. (1) Crop Pattern 5, which cultivates sugarcane only, and beef cattle breeding have produced the heaviest cost of all combinations observed, especially if measured in terms of per hectare and per livestock unit. The cost for this crop pattern is IDR 96,750,000.- while the cost for beef cattle breeding is IDR 10,865,000.-. Total cost of both works attains IDR 107,615,000.-. The reason behind this huge cost is that Crop Pattern 5 involves high production cost to cover the costs of land processing, land lease, and organic fertilizer; (2) Crop Pattern 5 has produced the highest revenue. The revenue of this crop pattern per hectare is IDR 110,450,000.- while beef cattle breeding per livestock unit gives revenue at IDR 14,900,000.-. Total revenue then is around IDR 125,350,000.-; (3) The income obtained from Crop Pattern 5 is IDR 13,700,000.- whereas beef cattle breeding delivers income around IDR 4,035,000.-. Total income is then IDR 17,735,000.-. (4) The highest balance between revenue and cost is 1.82 and it is found at Crop Pattern 4.
\end{abstract}

Key words: income, beef cattle breeder, crop pattern,

\section{Introduction}

Crop and animal husbandry are two sectors that can be integrated to be the complement of each other. Agriculture wastes provide useful ingredients to feed the livestocks, and in other hand, livestocks produce animal wastes to fertilize the crops. Recent development has been concentrated upon rural regions, especially to those known as agriculture production suppliers (or agriculture production centers). These regions were subjected to the program called as Growth Center Region (DPP) to optimize the power of rural regions. This activity is considered as very important because rural 
regions play important roles as: (1) the supplier of food materials to the population (in urban region); (2) the supplier of workers to the development project; (3) the supplier of raw materials to the industry; and (4) the producer of export commodity to abroad. To accelerate rural and agricultural developments, it would need a strong commitment and a moral responsibility to the development among governmental officers, communities, and privates. Only by this condition, agriculture development should be executed in effective, efficient, integrated and synchronic ways with the development in other sector with environmental friendly perspective.

One important program in the existing farming systems is an integrative farming program involving beef cattle breeding and crop planting. This program requires positioning beef cattle breeding in the region known as crop commodity supplier. The development of beef cattle breeding in this region is expected to stimulate farming activities at remote villages (hinterland) and those arounds. Beef cattle breeding would deliver raw material for food consumption of the community, and the products of this breeding may also be useful as export commodity that in turn could improve the regional economic structure. The opening of breeding work may also open employment and give opportunity to everyone to become selfemployed. It also helps reducing unemployment in rural region, especially at upstream, downstream, and marketing sectors of livestock production. To support this policy, particularly in relation with beef cattle breeding, then some information are needed such as about the potentials of natural resource and human resource; the supporting structures, strengths and weaknesses of livestock sector in certain region; the contribution of livestock sector to regional economic; and the future prospect of livestock development if reviewed from the aspects of economic, socioculture and supporting capacity of the region.

The development of beef cattle breeding in Jember Regency involves some efforts considered as important breakthroughs in livestock sector. These include: the adoption of the latest livestock technology such as conducting crossbreeding between local cattle and super quality cattle through artificial insemination (AI); the advanced control against diseases; the counseling to farmers to manage their livestock in grazing system rather than in shedding system; and the hand-over of work capital aid in expecting the meaningful change of income. However, until now, beef cattle breeding develops slowly. Very complex problems are emerging such as limited resource, narrow land, lack of capital and workers, and obsolete business management.

In achieving the ultimate goal, precisely good income, beef cattle breeders are subjected to the effect of two factors, respectively internal and external factors. Internal factor is related to breeder demography, such as age, education background, breeding experience (length of business), number of livestock owned, width of land owned, and number of household member. External factor concerns with worker wage, seed price, concentrate feed price, and others. This research attempts to understand the levels of cost, revenue and income of breeders if combined with various crop patterns.

Based on the background above, the objective of this research can be described as follows (1) to analyze the cost incurred at integrated farming involving beef cattle breeding and various crop patterns, (2) to estimate the revenue received from the integrated farming involving beef cattle breeding and various crop patterns, (3) to find out the income obtained from the integrated farming involving beef cattle breeding and various crop patterns; and (4) to acknowledge the balance of revenue and cost of the integrated farming involving beef cattle breeding and various crop patterns.

\section{Material and Methods}

The model of analysis on cost and revenue of crop planting and beef cattle breeding is described in the following equation:

$$
\pi=o_{i}{ }_{i=1}^{n}-I_{j}{ }_{j=1}^{m} P_{j}
$$

Where:

$\pi$ :income from the integrated farming of crop planting and beef cattle breedi (crop-livestock farming). 
O : output produced from crop-livestock farming.

I : costs expended in crop-livestock farming.

$\mathrm{P}$ : price of input and output of crop livestock farming.

\section{Results and Discussion}

\section{General Condition of Livestock Breeding} and Crop Pattern

\section{The Condition of Livestock Breeding}

Livestock breeding is the important work for the people of Umbulsari District because it supports the success of other farming kinds. Livestock breeding is also a meaningful work as the wealth materials and also as the saving.

The higher is the number of livestock to be kept, the greater would be the saving owned by the farmers. Therefore, the program of livestock development and dissemination in rural region would be very benefiting. It is quite relevant with efforts to improve livestock production and population, to increase employment, and to draw capitalization for rural development regarding the fact that the population of the District live in rural.

The development of livestock breeding is truly matched with the living of rural farmers because most of them work in crop planting and exploit farming waste into livestock feed. The condition of livestock breeding in Umbulsari District can be explained as follows.

In period 2012-2016, Umbulsari people raise two groups of livestock, respectively ruminants and poultries. The ruminants include beef cattle, buffalo, goat and sheep, while the poultries are broiler and crossbred chicken. The condition of livestock species and population in
Umbulsari District is displayed in table 1.

Table 1 indicates that in the last five years, beef cattle population is the highest compared to other ruminants, and the second is goat, followed by sheep and the lowest is buffalo. Besides in Umbulsari District, the population of buffalo is also the lowest in Jember Regency and even East Java Province. The reason is that people tend to use cattle rather than buffalo to plow their land.

Goat population increases in the last five years, and the ascension rate is quite faster than other ruminants such as buffalo, sheep and beef cattle. The reason is possibly that goat is dominantly used by farmers as the saving and goat is easily put on the sale or exchange.

\section{The Condition of Crop Pattern}

Farming activity in Umbulsari District is almost all dominated by dry land and wet land farmings. Dry land farming relies greatly on rainfall for the needs of water. It cultivates corn, cassava, sweet potato, and sugar cane. All these crops can be planted in singular system or intercropping system (tumpang sari). Wet land farming mostly grows rice, and usually it continues with corn. Other crops, such as soybean, sweet potato, green bean, and ground bean, are also planted, but rarely.

Some crop patterns have been applied in Umbulsari District:

(A) Wet Land Farming: (1) Rice 1 - Rice 2

(2) Rice 1 - Corn 2

(B) Dry Land Farming: (1) Cassava - Corn 2

(2) Corn 1 - Corn 2

(3) Sugar Cane

Crop patterns in dry land farming of Um-

Table 1 Livestock Species and Population in Umbulsari District (2016).

\begin{tabular}{|c|l|c|c|c|c|c|c|}
\hline \multirow{2}{*}{ No } & \multirow{2}{*}{ Species } & \multicolumn{5}{|c|}{ Year } & \multirow{2}{*}{ R(\%) } \\
\cline { 3 - 7 } & & 2012 & 2013 & 2014 & 2015 & 2016 & \\
\hline 1 & Beef Cattle & 9023 & 9768 & 10378 & 11973 & 14675 & 6.58 \\
2 & Buffalo & 120 & 139 & 169 & 187 & 205 & 10.04 \\
3 & Goat & 2075 & 2345 & 2678 & 2998 & 3215 & 11.59 \\
4 & Sheep & 435 & 485 & 548 & 583 & 612 & 8.96 \\
5 & Pure-bred chicken & 40000 & 45000 & 52500 & 57500 & 65000 & 12.93 \\
6 & Crossbred chicken & 19,250 & 20,550 & 22,200 & 35,725 & 39,950 & 21 \\
\hline
\end{tabular}

Source: The Official of Animal Husbandry for Jember (2016). . 
bulsari District are distinguished into three patterns, while wet land farming has two patterns. Farming schedule is arranged for two seasons, respectively: Planting Season I (first), or rain season, from the end of October or the beginning of November to the end of January or the early part of February, and Planting Season II (second) from the beginning of February to the end of May or the early part of June.

\section{The Analysis on Cost, Revenue, and Income \\ Cost Components of Crop-Livestock Farming \\ Cost components of crop-livestock farm-} ing in research location involving various crop patterns during a year are explained in Table 2.

Cost components in Rice1-Rice2 planting system (Crop Pattern I) with beef cattle breeding in terms of per hectare and per animal are: IDR 24,747,950.- for crop planting and IDR 10,452,000.- for beef cattle breeding. Total cost of this farming system is IDR 35,199,950.-. Cost components in Rice1-Corn2 planting system (Crop Pattern II) with beef cattle breeding measured by per hectare and per animal are: IDR 19,293,950.- for crop planting and IDR
10,502,000.- for beef cattle breeding. Total cost for this farming type is IDR 29,795,950,000.-. Moreover, cost components in Cassava-Corn2 planting system (Crop Pattern III) with beef cattle breeding in terms of per hectare and per animal are: IDR 15,337,950,000.- for crop planting and IDR 10,405,000.- for beef cattle breeding. Total cost for this farming method is IDR 25,742,950.-. Cost components in Corn1-Corn2 planting system (Crop Pattern IV) with beef cattle breeding measured by per hectare and per animal are: IDR 14,725,000.- for crop planting and IDR 10,755,000.- for beef cattle breeding. Total cost involved in this farming is IDR 25,480,000.Cost components in sugar cane planting system (Crop Pattern V) with beef cattle breeding in terms of per hectare and per animal are: IDR 96,750,000.- for crop planting and IDR $10,865,000$.- for beef cattle breeding. Total cost needed in this farming is IDR 107,615,000.-. Based on these findings, it can be said that integrated farming of Crop Pattern V, with sugar cane only, and beef cattle breeding has produced the highest cost of all crop patterns. The reason is that sugar cane planting needs high production cost involving costs for land processing, land rent, and organic fertilizer (Semaoen, 2006).

Table 2 Cost Components of Crop-Livestock Farming in Various Crop Patterns During a Year (Rupiahs)

\begin{tabular}{|c|c|c|c|c|c|c|}
\hline \multirow{2}{*}{ No } & \multirow{2}{*}{ Description } & \multicolumn{5}{|c|}{ Crop Patterns } \\
\hline & & I & II & III & IV & $\mathbf{V}$ \\
\hline $\begin{array}{l}\mathrm{I} \\
\mathrm{A} \\
1 \\
2 \\
3 \\
4 \\
5 \\
6 \\
7 \\
8 \\
9\end{array}$ & $\begin{array}{l}\text { CROP PLANTING } \\
\text { Cost Components } \\
\text { Land Tax } \\
\text { Water } \\
\text { Land Rent } \\
\text { Tool Depreciation } \\
\text { Seed } \\
\text { Pesticide } \\
\text { Fertilizer } \\
\text { Worker } \\
\text { Tractor Rent } \\
\text { Sub Total } \\
\\
\text { BEEF CATTLE } \\
\text { BREEDING } \\
\text { Cost Components } \\
\text { Ranch Depreciation } \\
\text { Tool Depreciation } \\
\text { Cattle Origin } \\
\text { Green Feed } \\
\text { Supplement Feed } \\
\text { Medicines } \\
\text { Sub total }\end{array}$ & $\begin{array}{r}125,950 .- \\
575,000 .- \\
5,477,000 .- \\
770,000 .- \\
1,140,000 .- \\
4,060,000 .- \\
4,540,000 .- \\
5,950,000 .- \\
2,400,000 .- \\
\mathbf{2 4 , 7 4 7 , 9 5 0 . -}\end{array}$ & $\begin{array}{r}150,700 .- \\
460,000 .- \\
4,774,000 .- \\
790,000 .- \\
1,000,000 .- \\
3,120,000 .- \\
2,700,000 .- \\
5,100,000 .- \\
1,300,000 .- \\
\mathbf{1 9 , 2 9 3 , 9 5 0 . -}\end{array}$ & $\begin{array}{r}140,950 .- \\
350,000 .- \\
3,787,000 .- \\
795,000 .- \\
800,000 .- \\
1,950,000 .- \\
2,400,000 .- \\
3,950,000 .- \\
450,000 .- \\
\mathbf{1 5 , 3 3 7 , 9 5 0 . -}\end{array}$ & $\begin{array}{r}140,000 .- \\
360,000 .- \\
4,300,000 .- \\
775,000 .- \\
1,000,000 .- \\
2,050,000 .- \\
2,450,000 .- \\
3,800,000 .- \\
350,000 .- \\
\mathbf{1 4 , 7 2 5 , 0 0 0 . -}\end{array}$ & $\begin{array}{r}365,000 .- \\
685,000 .- \\
6,900,000 .- \\
175,000 .- \\
1,500,000 .- \\
2,950,000 .- \\
8,350,000 .- \\
10,750,000 .- \\
65,000,000 .- \\
\mathbf{9 6 , 7 5 0 , 0 0 0 . -}\end{array}$ \\
\hline
\end{tabular}




\section{Revenue of Crop-Livestock Farming}

Revenue of crop-livestock farming in this research comes from many sources, such as: the harvests of cassava, corn and sugar cane; the sale of cattle; the output from the use of cattle power; and the sale of cattle dung.
26,780,000.- for crop planting and IDR $14,800,000$.- for beef cattle breeding. Total revenue obtained from this farming is IDR 41,580,000.-. Revenue of Crop Pattern V with beef cattle breeding in terms of per hectare and per animal is counted at IDR 110,450,000.- for

Table 3 Revenue of Crop-Livestock Farming in Various Crop Patterns During a Year (Rupiahs)

\begin{tabular}{|c|l|l|l|l|}
\hline \multirow{2}{*}{ No } & \multirow{2}{*}{ Crop Pattern } & \multicolumn{3}{|c|}{ Revenue } \\
\cline { 3 - 5 } & & Crop Planting & $\begin{array}{c}\text { Beef Cattle } \\
\text { Breeding }\end{array}$ & Total \\
\hline 1. & Rice1-Rice2 & $36,450,000 .-$ & $14,770,000 .-$ & $51,220,000 .-$ \\
2. & Rice1-Corn2 & $28,620,000 .-$ & $14,350,000 .-$ & $42,970,000 .-$ \\
3. & Cassava-Corn2 & $24,575,000 .-$ & $14,650,000 .-$ & $39,225,000 .-$ \\
4. & Corn1-Corn2 & $26,780,000 .-$ & $14,800,000 .-$ & $41,580,000 .-$ \\
5. & Sugar Cane & $110,450,000 .-$ & $14,900,000 .-$ & $125,350,000$. \\
\hline & & & & - \\
\hline
\end{tabular}

Revenue of Crop Pattern I with beef cattle breeding in term of per hectare per animal has reached IDR 36,450,000.- for crop planting and IDR 14,770,000.- for beef cattle breeding. Total revenue for this farming system is IDR 51,220,000.-. Revenue of Crop Pattern II with beef cattle breeding measured by per hectare and per animal has attained IDR 28,620,000.for crop planting and IDR 114,350,000.- for beef cattle breeding. Total revenue obtained from this farming type is IDR 42,970,000.-. Moreover, revenue of Crop Pattern III with beef cattle breeding in terms of per hectare and per animal has been counted at IDR 24,575,000.for crop planting and IDR 14,650,000.- for beef cattle breeding. Total revenue of this farming method is IDR 39,225,000.-. Revenue of Crop Pattern IV with beef cattle breeding measured by per hectare and per animal includes IDR crop planting and IDR 14,900,000.- for beef cattle breeding. Total revenue attained from this combination is IDR 125,350,000.-. Means rate of crop planting per hectare has been IDR $45,375,000$.- while that of beef cattle breeding per animal is about IDR 14,694,000.-. total revenue of all the works would be IDR 60,069,000.-

\section{Income of Crop-Livestock Farming}

Income of this crop-livestock farming is derived from the subtraction of the revenue with the cost. The income of this crop-livestock farming for a year is presented in Table 4.

The findings can be explained as follows. Income of Crop Pattern I is counted at IDR 11,702,000.- per hectare for crop planting and IDR 4,318,000.- per animal for beef cattle breeding. Total income in this farming type is IDR 16,020,000.-. The income of Crop Pattern II

Table 4 Income of Crop-Livestock Farming in Various Crop Patterns During a Year (Rupiahs)

\begin{tabular}{|c|l|c|c|c|}
\hline \multirow{2}{*}{ No } & \multirow{2}{*}{ Crop Pattern } & \multicolumn{3}{|c|}{ Income } \\
\cline { 3 - 5 } & & Crop Planting & $\begin{array}{c}\text { Beef Cattle } \\
\text { Breeding }\end{array}$ & Total \\
\hline 1. & Rice1-Rice2 & $11,702,000 .-$ & $4,318,000 .-$ & $16,020,000 .-$ \\
2. & Rice1-Corn2 & $9,325,000 .-$ & $3,848,000 .-$ & $13,173,000 .-$ \\
3. & Cassava-Corn2 & $9,237,000 .-$ & $4,245,000 .-$ & $13,482,000 .-$ \\
4. & Corn1-Corn2 & $12,325,000 .-$ & $4,045,000 .-$ & $16,370,000 .-$ \\
5. & Sugar Cane & $13,700,000 .--$ & $4,035,000 .-$ & $17,735,000 .-$ \\
\hline & Means Rate & $11,257,800 .-$ & $4,098,200 .-$ & $15,356,000 .-$ \\
\hline
\end{tabular}


reaches IDR 9,325,000.- per hectare for crop planting and IDR 3,848,000.- per animal for beef cattle breeding. Therefore, total income from this farming method is IDR 13,173,000.-. Income of Crop Pattern III has attained IDR 9,237,000.- per hectare for crop planting and IDR 4,245,000.- per animal for beef cattle breeding. Total income in this farming combination would be IDR 13,482,000.-. Income of Crop Pattern IV has reached IDR 12,325,000.per hectare for crop planting and IDR 4,045,000.- per animal for beef cattle breeding. Total income obtained from this farming is IDR 16,370,000.-. Income in Crop Pattern V is IDR 13,700,000.- per hectare for crop planting and IDR 4,035,000.- per animal for beef cattle breeding. Total income derived from this farming would be IDR 17,735,000.-

\section{The Balance of Revenue and Cost in Crop- Livestock Farming}

The balance of revenue and cost in croplivestock farming is the result from dividing the revenue with the cost in crop-livestock farming. This result is popularly called as R/C Ratio. positive means rate should give a justification that certain farming, in this case involving crop planting and beef cattle breeding, is reliable. Descriptive study usually verifies the reliability of the observed work based on means rate, and it is consistent with the suggestion of Anita Ariani Murpa, Nurani Sirajuddin, \& Ikrar Mohammad Saleh (2015) who reported the means rates of annual income obtained from different number of cattle kept and also its $\mathrm{R} / \mathrm{C}$ Ratio. Their findings were: 8 cattles resulting in income of IDR 21,901,667.- with $\mathrm{R} / \mathrm{C} 2.9 ; 7$ cattles delivering income of IDR 20,420,417.- with R/C 3.1; 5 cattles producing income of IDR $12,079,444$.- with $\mathrm{R} / \mathrm{C} 2.3 ; 4$ cattles giving income of IDR 9,356,500.- with R/C 2.0; 3 cattles bestowing income of IDR 7,232,917.- with R/C 1.8; 2 cattles delivering income of IDR 5,201,146.- with R/C 1.8; and 1 cattle producing income of IDR 2,507,500 with R/C 1.8 .

Table 5 Revenue/Cost Ratio of Crop-Livestock Farming in Various Crop Patterns During a Year (Rupiahs)

\begin{tabular}{|l|l|l|l|l|}
\hline No & Crop Pattern & Revenue & Cost & $\begin{array}{l}\text { R/C } \\
\text { Ratio }\end{array}$ \\
\hline 1. & Rice1-Rice2 & $36,450,000 .-$ & $24,747,950 .-$ & 1.47 \\
2. & Rice1-Corn2 & $28,620,000 .-$ & $19,294,900 .-$ & 1.48 \\
3. & Cassava-Corn2 & $24,575,000 .-$ & $15,337,950 .-$ & 1.60 \\
4. & Corn1-Corn2 & $26,780,000 .-$ & $14,725,000 .-$ & 1.82 \\
5. & Sugar Cane & $110,450,000$. & $104,875,000$. & 1.05 \\
& & - & - & \\
\hline & Means Rate & $45,375,000 .-$ & $35,796,160 .-$ & 1.27 \\
\hline
\end{tabular}

As shown in Table 5, $\mathrm{R} / \mathrm{C}$ ratio for each crop pattern can be explained as follows: 1.47 for Crop Pattern I; 1.48 for Crop Pattern II; 1.60 for Crop Pattern III; 1.82 for Crop Pattern IV; and 1.05 for Crop Pattern V. Result also indicates that the means rate of $\mathrm{R} / \mathrm{C}$ ratio is 1.27 . This ratio is positive which means that farmers still get profit despite its small rate. According to Clive Guy, Lien K. Sabur, P. Simanjuntak \& P. F. Maspaitella (1988),

\section{Conclusion}

Based on analysis and discussion, several conclusions are made: (1) The integration between Crop Pattern 5, which cultivates sugarcane only, and beef cattle breeding has produced the heaviest cost of all combinations observed in terms of per hectare and per animal. The cost for crop planting is IDR 96,750,000.- while the cost for beef cattle breeding is IDR $10,865,000$.-. Total cost of both works attains IDR 107,615,000.The reason behind this huge cost is that Crop Pat- 
tern 5 involves high production cost to cover the costs of land processing, land rent, and organic fertilizer. (2) Crop Pattern 5 also produces the highest revenue. The revenue per hectare from Crop Pattern 5 is IDR 110,450,000.- while beef cattle breeding per livestock unit gives revenue at IDR 14,900,000.-. Therefore, total revenue of this farming system is IDR $125,350,000 .-$. (3) The income obtained from Crop Pattern 5 is IDR 13,700,000.- whereas beef cattle breeding delivers income around IDR 4,035,000.-. Total income of this farming type is IDR 17,735,000,, (4) The highest balance of revenue and cost (R/C Ratio) is 1.82 found at Crop Pattern 4.

\section{Suggestion}

Total cost of crop-livestock farming is still quite difficult to afford by farmers. Therefore, the government should provide work capital aid for farmers without requiring them to submit the collateral or to comply with complex rules, or even by providing very low interest of loan which must be affordable to farmers.

\section{Reference}

Murpa, A.A., Sirajuddin, N., \& Saleh, I.M. (2016). Analisis Pendapatan Peternak Usaha Sapi Potong Pada Pola Bagi Hasil Teseng Di Desa Lempang, Kecamatan Tanete Riaja, Kabupaten Barru. Makasar: Unhas.

Semaoen, I \& S.M. Kiptiyah (2006). Distribusi Pendapatan dan Kemiskinan di Desa Miskin Jawa Timur. Jurnal Penelitian ilmu-ilmu Sosial, 9(2).

Singarimbun, M., \& S, Efendi. (1982). Metode Penelitian Survai. Jakarta: PT Pustaka, Lembaga Penelitian Pendidikan dan Penerangan Ekonomi Social (LP3ES) Indonesia Jakarta. 